pluralities and diversities that sometimes breed conflict, and many persons are no longer willing to give their allegiance to any centre. Democracy in the contemporary neo-liberal model functions like a bubble in a very delicate state of existence that can easily burst and have its life-sustaining contents spilt (also see Ross, Nilsson \& Hewitt 2014). The trust that democracy demands is used by government to violate liberties in secret, such as reading emails and listening to telephone calls in the name of protecting national security, and all of this is done beyond the reach of democratic accountability (De Wet \& Fairweather 2013). ${ }^{1}$ Therefore, the kind of spirituality that is needed to facilitate full and meaningful participation of citizens requires an overhaul of the democratic project. This renewal journey will eschew the agenda that calls for a primary focus on protecting institutional survival and focus instead on being willing to risk creating space for people to express their felt needs and to find a common path to benefit the common good.

\section{Postcolonial lens}

The key terms of this article are all controversial and are open to different kinds of contextual understandings. Therefore, I shall approach the topic by employing a postcolonial lens clothed in Rastafari hermeneutics to interrogate the loaded terminologies that are in the baggage bequeathed by systems of power that act in the interest of the influential few. According to Namsoon Kang (cf. Van der Water et al. 2011:109), a postcolonial lens in conversation with spirituality and democracy acknowledges that '... the residue of colonialism is strongly influential on construction of discourses and praxes, education, language, culture, geopolitics and economy ...' Implicit in this discourse is the colonial mentality which, in the context of 'missionary Christianity', bequeathed a spirit to patronise, dominate and control others (Van der Water et al. 2011:109).

Kang adopted the notion of postcolonialism as '... the discourse of oppositionality which colonialism brings into being ...', and it functions as the discourse of critical resistance and liberation from colonial confinement and oppression (Van der Water et al. 2011:113). Using Kang's perspectives, this article endorses the use of the concept to '... offer a critical analytical tool to dismantle the implicit or explicit colonial mentality and practice ...' and also serves as '... an analytical lens through which one can approach the issue of power' (Van der Water et al. 2011:113). Issues that surround spirituality and democracy are rooted in the logic of power and domination and are therefore open for piercing questions that can expose hidden agendas and disrupt the status quo in order to create liminal spaces that can facilitate boundary crossing into new spheres of meaningful living. Therefore, in this presentation, a postcolonial critique is utilised to deconstruct this false construct of democracy that is perpetrated by an unjust neo-liberal economic order that is doing so much violence in the global market place. It is newspaper (2013) South African citizens face a closer scrutiny of their private communication than USA citizens. somewhat contradictory to speak about Christian spirituality and democracy because, for most of her history, the church has not embraced democratic models of governance. Indeed, it seems to be comfortable with monarchical and dictatorial forms of governance. According to Fytte Klausen (cf. Katznelson \& Jones 2010:314-335), European Christianity has been facilitating the emergence of secularism since 1945. Therefore, in the modern expression of Christianity in certain European contexts, it can be argued that Christian spirituality has uncritically entered into strategic partnership with democratic values and structures.

\section{What spirituality means?}

Although there may be disagreement on what 'spirituality' means, its reality is acknowledged and experienced in every human community that seeks deeper meaning and purpose to the challenges of life. Spirituality therefore refers to the interior meaning of our humanity (Swidler 2013). All religious and ideological systems sustain their identity, vocation and witness through an embedded spirituality that is not a fixed concept, but dynamic in that it is always transforming reality by embracing and relinquishing people's allegiance from time to time. It has to do with how we are being grasped by reality when we are in a liminal space. Therefore, to vote for democracy does not necessarily mean to vote for Christianity, because all religions possess different forms of spirituality. Spirituality is an innate and intangible life-sustaining reality that communicates the quality, condition or uniqueness of one's identity. It is an indispensable resource that ultimately transforms the individual from being possessed with selfish agendas to focusing on the common good of the entire community (Sheerattan-Bisnauth 2009). Within the Christian religion, spirituality is focused on lifestyles that demonstrate sacredness or holiness, mysticism and devoutness in order to achieve a specific purpose. If Christian spirituality is to inform democracy, it must bequeath fidelity to the practice of high moral standards in its political ethic, an allegiance to a transcendent being that holds all creation to account for its stewardship and a commitment to learning by doing.

\section{Spirituality of paternalism}

The undergirding spirituality that Euro-centric missionary Christianity bequeathed in relation to participating in the political realm called for trusting the state and the elected government based upon the biblical mandate given by St Paul (Rm 13:1-2) that all elected governments are divinely approved and should therefore be unconditionally obeyed because '.. the authorities that exist are appointed by God'. This kind of spirituality was built on uncritical alliance with political paternalism. The citizens were duped into surrendering their critical judgement concerning the decisions that were being made on their behalf because they were taught that leaders who are elected through a democratic process will work for their best interest. However, contemporary expressions and experiences of democracy are being called into question by people. The inadequacy of the democratic process to meet felt needs have resulted in 
distrust of leaders and institutional systems of government, the judiciary, education, commerce and religion that are key stakeholders in the democratic process that is failing the people.

\section{Democracy in crisis}

The word 'democracy' conjures images of free and fair elections in which people vote to determine models of governance of different institutions and the leaders who will manage the process. Democracy at its best requires that people are fully involved in the process through which their representatives are elected and constitutional laws are formed. Although democracy is promoted as a phenomenon linked to Western philosophy of governance, it has evolved into a global phenomenon with different contextual constructs. Democracy is a kind of belief system that nurtures disciples to become well-qualified apologists in defence of its claims to be an excellent way of living. The political journey from communism to Western-style democracy has been accompanied by painful upheavals characterised by uncontrollable get-rich-quick schemes operated by powerful elites. Sometimes it seems that democracy brings out the worst in humans, features which other forms of governance would put under control (Haqqani 2013).

Underlying any democratic practice of good governance is the right of every citizen to go to an independent judicial system that is free from party or government interference to seek justice for what is perceived to be a gross wrong that has been done. This practice which is usually protected by the constitution is informed by a spirituality rooted in fairness that keeps in check the human capacity to act unfairly out of self-interest rather than for the common good. Good governance calls for holding accountable the performance management of those who exercise power over others.

\section{How does spirituality relate to democracy?}

It appears somewhat odd that the title of this article links spirituality with democracy. Indeed, it implies that, as a result of historical conditioning, Western nations in particular have sacralised the institution. If democracy is meant to be the best engine that drives national governance towards agreed common objectives, then spirituality is the engine oil that lubricates and cleans to ensure that the journey is not compromised because of engine failure. Therefore, spirituality has an important role to play in equipping its adherents to hold the democratic system and process accountable to the people and their needs. Democracy is sometimes presented as a kind of god that demands worship from all citizens in order for them to experience justice and peace.

There are different spiritualties of democracy. The recent episode of crisis with the spirituality that underpins the practice of democracy went on global display within the USA when the leaders within the legislature failed to agree on their budget, and it resulted in the closure of the Federal
Government for two weeks (Parker 2013). The inability of the legislature to find consensus on what constituted the common good of the nation serves as a potent signpost that there can be rogue spirituality that informs different models of governance. The dysfunctional behaviour almost brought the country to default on its debt. The leadership in this case created a crisis in governance as they represented an extreme version of Christian conservatism allied with an extreme and irresponsible political conservatism of the Tea Party movement and the Republican Party. Their actions communicated a negative view of conservative religion, suggesting that it is addicted to a dysfunctional form of spirituality that results in bad governance and deepening dysfunction in pluralistic societies. Closed in self-righteous garments in the pursuit of their own self-interest, they held the nation and the world to ransom for the sake of their narrow ideological agenda. For their model of democracy to work, the right of others with whom they disagree must be curtailed. Only a more life-giving set of spiritual values that can neutralise and make impotent the power of selfinterest can restore the trust in democratic values that serve the common good.

\section{Misplaced concreteness}

Daley and Cobb Jnr. (1989:25), in their seminal text For the common good, make reference to the warning of Alfred North Whitehead about 'the fallacy of misplaced concreteness'. According to Dale and Cobb (1989), the misplaced concreteness of the market claims that:

Its strengths are to be found in its capacity to use independent, decentralised decisions to give rise not to chaos but to spontaneous ... Individual consumers know their preferences better than anyone else and act directly to satisfy them in the marketplace. Individual producers know their own capacities and options better than anyone else and they too act on this information in the market. (pp. 44-45)

I would like to use the concept of misplaced concreteness that is attributed to the global market system to be applied to the global phenomenon of democracy. Economic globalisation that created the market system is also directly connected to the democratic system of governance and is therefore also in crisis. In Western economies, the market is given divine and infallible status. It is fused into the democratic model of governance and made sacred as the most efficient institution for the production and allocation of resources. There is an insatiable competitive drive for profit that ensures that there are winners (those who know best and use market information) and losers (those who fail to know and use market information) (also see Ross et al. 2014). A democratic society that is built on spiritual values but morally misapplied lends itself to becoming a dysfunctional and destructive society. This economic beast, according to Matthews (2013), George Chunakara, thrives on unrestrained self-interest even at the expense of the common good of the community. One can therefore argue that the capitalist neo-liberal concept of free enterprise has hijacked democracy as an indispensable partner to serve its goals through the control of capital and labour. Therefore, the contemporary expression of democracy 
is embedded within the construct of the market economy. The most important political participants in this economy are those whose contributions are valued by the market to be of strategic importance (Hewitt in Matthews 2013:105).

\section{Rastafari discourse on democracy}

Rastafari constitutes an African-Jamaican postcolonial movement of resistance against the global forces of oppression. According to noted Jamaican scholar, Ashley Smith (1991):

Rastafarianism represents an acute reaction to European domination. Its advocates prefer to dissociate themselves from what would be considered distinctively Christian. It is a violent protest against what is perceived to be inimical to the very existence of the victims of white domination in the region. It regards the language of Christianity about non-Europeans as imperious and offensive and advocates not only a new religious language for black people but a new imagery for the communication of black religious values. It is particularly sensitive about the authority of the black male and the structure of the black family since (they) have been the greatest casualties of the de-culturation of the race by the white colonisers and exploiters. (p. 57)

Marcus Mosiah Garvey, (Martin 1986) the Pan-Africanist Jamaican whose philosophy and opinions contributed significantly to the birth of Rastafari, offers some poignant comments on black people's participation in the social system of his society:

You must never sell yourself to a politician ... Always make your vote count for bringing about reforms you and others think are right for your community. Never exchange it for money ... In countries where as a race, you are not allowed to vote, always work to get the vote, by way of reform. Use the help of everybody, but have political power to bring about changes that will give you the vote. Otherwise you will be governed without your consent. To vote is to make the attempt to share in the government of the community. You should never be a political slave in a community because others will take advantage of you. (pp. 72-73)

However, Rastafari spirituality has moved beyond Garvey's perspective to become much more radical. The birth of the movement emerged out of a socio-political crisis with the colonial era of governance in Jamaica in 1930. This was an era when the economic depression within the USA resulted in a major socio-economic dislocation within the Jamaican society The movement therefore represented a socio-political and religious response of the poor urban dwellers to British colonialism in partnership with its local beneficiaries aligned to the white value system that was dedicated to keep AfricaJamaicans in servitude. Marcus Garvey's teachings were employed to create an alternative system of governance. He is claimed to have prophesied that African-Jamaicans should '[l]ook to Africa when a black King shall be crowned, for deliverance is near' (Norris 1962:44). Embodied in the Rastafari name is the essence of their identity. The former Ras Tafari Haile Selassie, who became Emperor of Ethiopia in 1930, was acclaimed as the Messiah of the black race.

It was the radical response of early Rastafari to their context characterised by underdevelopment of peoples of African descent that resulted in their persistent critique of the model of governance within society. They called for putting up resistance against 'politicians and their poly-tricks (Afari 2007:217-221). Although Rastafari is a religio-political movement with an Afro-centric ${ }^{2}$ ideological worldview, its commitment to fighting against systems of oppression has made it hostile to the inherent deception and corruption within the 'Westminster model of parliamentary democracy' and its accompanying party politics. ${ }^{3}$

Participation in politics has come to mean much more than voting in national elections. Rastafari Damion Marley's critique of Jamaican democracy in the post-independence era in his song 'Welcome to Jam Rock' (2005), presents a potent criticism of the system:

Welcome to Jam down, poor people ah dead at random

Political violence, can't done, pure ghost and phantom

The youth dem get blind by stardom

Now the kings of kings ah call

Old man to Pickney, so wave unnuh hand if you with me

To see the sufferation sick me

Dem suit no fit me, to win election dem trick we

Then dem don't do nuttin' at all. (n.p.)

This critique by Damion Marley serves as a signpost of the capacity of democratic systems to become corrupted by unscrupulous power-hungry actors. He asserts that, in a context of economic survival of the poor within Jamaica, the practice of democracy serves the corrupt players in the system. His conclusion is that the system does not fit! It does not function in the interest of the poor who are killed at random in political violence. The suffering of the poor is immeasurable, and then in the name of democracy, the power hungry call elections which in practice is a trick to deceive the poor because in the end they will do nothing to change the plight of the poor.

Therefore, processing the tools to expose the masks that these deceptive leaders use in their management of the democratic process is a critical spiritual resource. Democracy that is meant to foster good constitutions and laws that facilitate good governance, political stability, economic and social development and protecting the common good is often hijacked by powerful economic forces that bribe politicians who are susceptible because they lack strong political ethics. Good governance is therefore a prerequisite for peace, respect for human rights and social progress and just economic growth.

According to Rastafari hermeneutics, if democracy is to serve the felt needs of the people, then its ultimate objective must be to facilitate restorative and integrative justice for the oppressed on the margins of society (Barnett 2012:26). Rastafari employs an Afro-centric framework for its worldview in which the African ideal is repositioned at the centre of analysis and not at the periphery (Barnett 2012:160). Their philosophical outlook 2. Rastafarians used language, dress, hairstyle, religious beliefs, music, family life
and the smoking of ganja as their way of turning their backs on the Western value system of the Jamaican establishment.

3.See Lijphart (1999) for an in-depth description of the model. 
is to reconstruct a more life-giving community through self-reliance and to remove any obsession with being victims. They have given up the expectation that political authorities will respond to their cries and regard official political participation as being mixed up with 'politricks' (Barnett 2012:291). Rastafari regards dysfunctional systems of government as being part of a 'Babylonian system' that exist to deny the poor and oppressed their God-given rights. Hewitt (2012) argues that:

The concept of Babylon is loaded with deep symbolism. They adopted the term Babylon from the Hebrew and Christian scriptures that identified it as an evil and oppressive force that works against the just development of human societies. Babylon seeks to embody and control the people of God by giving them false values and institutions. (p. 32)

The global face of Rastafari, Bob Marley (1979), offers the most authentic critique of democratic governance in Jamaica is his song 'Babylon System':

\section{We refuse to be}

What you wanted us to be;

We are what we are:

That's the way (way) it's going to be. You don't know!

You can't educate I

For no equal opportunity:

(Talkin' 'bout my freedom) Talkin' 'bout my freedom,

People freedom (freedom) and liberty!

Yeah, we've been trodding on the winepress much too long:

Rebel, rebel!

Yes, we've been trodding on the winepress much too long:

Rebel, rebel!

Babylon system is the vampire, yea! (vampire)

Suckin' the children day by day, yeah!

Me say: de Babylon system is the vampire, falling empire,

Suckin' the blood of the sufferers, yea-ea-ea-ea-e-ah!

Building church and university, wo-o-ooh, yeah! -

Deceiving the people continually, yea-ea!

Me say them graduatin' thieves and murderers;

Look out now: they suckin' the blood of the sufferers (sufferers).

Yea-ea-ea! (sufferers)

Tell the children the truth;

Tell the children the truth;

Tell the children the truth right now!

Come on and tell the children the truth;

Tell the children the truth;

Tell the children the truth;

Tell the children the truth;

Come on and tell the children the truth.

'Cause - 'cause we've been trodding on ya winepress much too long: Rebel, rebel!

And we've been taken for granted much too long: Rebel, rebel now!

(Trodding on the winepress) Trodding on the winepress (rebel): got to rebel, $\mathrm{y}^{\prime}$ all (rebel)!

We've been trodding on the winepress much too long ye-e-ah! (rebel)

Yea-e-ah! (rebel) Yeah! Yeah!

From the very day we left the shores (trodding on

the winepress)

Of our Father's land (rebel),

We've been trampled on (rebel),

Oh now! (we've been oppressed, yeah!) Lord, Lord, go

to ... (n.p.)
Through the haunting repetition of some keywords, Marley communicates a Rastafari discourse of resistance against the dominant order. The following constitutes the key tenets of his argument against the Babylon system:

- Rastafari will not compromise nor surrender their identity to fit into the dominant order that wants to prescribe their place in society.

- The system's claim to educate people for equal opportunity is deceptive. The focus must be on giving people freedom and liberty.

- The long history of oppression of the people by the system calls for rebellion not appeasement.

- The Babylon system is a life-denying system that sustains itself by 'sucking the blood' of sufferers. This constitutes a system that is evil to the core.

- The model of governance in alliance with religious and educational instructions is built on deception and therefore mis-educating people who end up becoming 'thieves and murderers'.

- Truth telling, especially to the children, must not be compromised.

Rastafari are therefore reluctant participants in the democratic process because they identify too many life-denying and dehumanising forces at work in the system (Prahlad Anand 2001). However, the movement's classical opposition and isolation to political engagement has experienced routinisation (Barnett 2012:292) and therefore had to adapt to the contemporary post-independence realities of politics that necessitates some form of political engagement to protect their human rights. Increasingly, the movement in Jamaica is realising that, without political power, their political ideals will not be realised. There have been cases where segments of the Rastafari community have organised themselves to compete as a party in national elections, but they have not been successful (Barnett 2012:293-296). Others have joined the mainstream political parties to contest parliamentary seats. However, what makes their discourse so inviting is the deep propensity of their spirituality to put up resistance against those forces. They do this using disarming weapons of 'words', 'sounds' and music to make the rogue power impotent.

\section{Resources that halt withdrawal from the democratic process}

Life in a healthy democracy requires active participation by a large majority of the citizens. The growing withdrawal from public participation in the democratic process is due in part to people's disappointment with the political managers of the system. The post-modern, neo-liberal world with its deification of the individualist and consumerist's ethic has resulted in societies with foundations built on fragmentation. It is this phenomenon that has given rise to the increasing emphasis on the need for spirituality (SheerattanBisnauth 2009:32).

If the spirituality for democracy is to work in partnership with political and economic democracy for development, it 
requires an environment that creates a safe space for every person to express his or her political perspective on any issue that affects personal or communal well-being. Therefore, in this era of information overload, the citizen must be proactive in holding democratic systems and elected leaders accountable. There is a need to entertain a healthy suspicion of any form of conservative religion that is in uncritical partnership with democracy, because what is presented as majority rule may result in totalitarian oppression by the majority.

The enslaving capacity of economic globalisation that has co-opted global democracy to support its agenda of total control of the global economy necessitates the emergence of an alternative spirituality of resistance to maintain human dignity over life-denying forces (The Church and Economic Globalisation 2007). In addition, there is a need for urgent partnerships that are united in facilitating 'fullness of life for all creation' as a strategy of struggle and resistance against neo-liberal, global economic disorder. This can only be achieved through joint action that works for the emergence of new, legal, life-supporting structures that are open to active participation from all sections of society.

\section{Finding the political spirituality to make change}

The most difficult challenge in any democratic society is finding the political will to make the change. The argument for spirituality for democracy is based on the premise that spirituality is the oil that will energise the democratic process that empowers the participants to democratise structures in order that they become more life giving. Eugene C. Bianchi (n.d.) proposed some of the key principles on 'spirituality of democracy' as a signpost to offer some possible resources that can enhance contemporary democratic participation.

The spiritual resources needed for democratic participation should include the following assets:

- Openness to the exchange of ideas and learning from and with others who are different from us. This experience allows participants to move from narrowly embedded perspectives on issues to more global deliberative perspectives that facilitate change.

- Mutual respect: Affirmation of the immeasurable worth of the other is an indispensable requirement to foster and build democratic values. Wherever and whenever the human dignity of persons, regardless of race, class, creed, economic worth or religion is valued an affirmed, the democratic process is enhanced.

- The discussion and contributions of those in the local communities need to be taken seriously. A core principle in democratic practice is to ensure that the voices of those at the local level are listened to and acted upon. A radical spirituality that empowers the democratic process models the example of Jesus who '... relates to and embraces those who are most marginalized in society, in order to confront and transform all that denies life' (Keum 2013:15).

- People must be given space to form their own life-giving structures in diverse and multiple centres at local levels to meet their felt needs. The tenet of spirituality eschews the desire to dominate and control others and put in check intimidating and toxic forms of centralisation.

- What is needed is an inclusive spirituality that empowers for free and fair participation in election: Spirituality should facilitate giving individuals a deep feeling of self-worth, inclusivity and being valued to participate effectively in the democratic process. At the Eucharistic Table, the words of Jesus are used to declare his commitment to building an inclusive community: 'All are welcomed ... no one will be turned away.'

- Limits to office holding are encouraged: In order to mentor new leaders and invest in succession planning, term limits to office bearers are encouraged in order that the democratic process of choosing leaders is not monopolised by powerful elites.

- Team leadership with separate authorities and inbuilt checks and balances are needed: The spirituality that undergirds democratic governance is rooted in servanthood that serves in a humble, down to earth style with the goal of empowering people to help themselves. Therefore, such a spiritual resource focuses on participation that ensures that there are checks and balances in the different levels of governances because, according to William Pitt the Elder, Earl of Chatham and British Prime Minister from 1766 to 1778 , in a speech to the UK House of Lords in 1770, 'Unlimited power is apt to corrupt the minds of those who possess it' (The Phrase Finder n.d.). This implies that inbuilt checks and balances within institutional frameworks are in essence forms of spiritual disciplines to keep humankind from going off course and to protect them against abuse of power.

- Effective democratic governance requires the indispensable spiritual resource of accountability: That is the key reason for holding elections. Leaders are called upon to give an account of their stewardship and to motivate why they should be trusted again to serve and represent the people.

\section{Conclusion}

This article began with the assertion that, in spite of the commendable achievements that have been accomplished by diverse democratic projects around the world, the contemporary experiences confirm that democracy is experiencing a crisis of confidence in meeting the needs of many people. It argues that a life-giving spirituality for democracy is needed that embodies a vision of an inclusive community in which all participants, regardless of their identity, are fully included and given safe space to be fully human in order to achieve fullness of life. Through the use of a Rastafari postcolonial lens, a discourse on the 'Babylon system' of governance was presented that critiqued the spirituality that undergirds the Western expression of 
democracy. The experiences of many persons, especially those that live on the margins of society (especially women and children) in democratic countries, attest to power systems that exclude rather than include into meaningful participation. The article concludes with a call for identifying resources that will halt the withdrawal of persons who are disillusioned with the democratic process that fails to bring about 'life-giving' change in their contexts. The most urgent need is for a political spirituality that is willing to sacrifice and put into action transformational leadership behaviour that ensures democratic governance is meeting the felt needs of the people.

\section{Acknowledgements Competing interests}

The author declares that he has no financial or personal relationship(s) which may have inappropriately influenced him in writing this article.

\section{References}

Afari, Y., 2007, Overstanding Rastafari, Senya-Cum, Kingston.

Barnett, M. (ed.), 2012, Rastafari in the new millennium, Syracuse University Press, Syracuse.

Bianchi, C.E, n.d., A spirituality of democracy, viewed 13 November 2013, from http:// www.religion.emory.edu/faculty/bianchi/arccdemo.htm

Daley, H.E. \& Cobb, J.B. Jnr., 1989, For the common good: Redirecting the economy towards community, the environment, and a sustainable future, Beacon Press, Boston.

De Wet, P. \& Fairweather, A., 2013, Spying far worse in South Africa than the US, The Mail and Guardian Newspaper online, viewed 05 June 2014, from http://mg.co. za/article/2013-06-14-00-spying-far-worse-in-south-africa
Parker, A., 2013, Government shuts down in budget impasse, viewed 12 November 2013, from http://www.nytimes.com/2013/10/01/us/politics/congress-shutdowndebate.html?_r=0

Haqqani, H., 2013, 'Islamist and democracy: Cautions from Pakistan', Journal of Democracy, viewed 17 October 2013, from http://www.journalofdemocracy.org/ sites/default/files/Haqqani-24-2.pdf

Hewitt, R., 2012, Church and culture, Cluster Publications, Pietermaritzburg.

Katznelson, I. \& Jones, S.G., 2010, Religion and the political imagination, Cambridge University Press, Cambridge UK. http://dx.doi.org/10.1017/CBO9780511779510 Keum, J., 2013, Together towards life, WCC Publications, Geneva.

Lijphart, A., 1999, Patterns of democracy, viewed 13 November 2013, from http:// www.sirius.utwente.nl/wordpress/wp-content/uploads/2011/12/EDGE.pdf

Marley, B., 1979, Babylon system, viewed 04 June 2014, from http://www.azlyrics. com/lyrics/bobmarley/babylonsystem.html

Marley, D., 2005, Welcome to Jam Rock, viewed 12 November 2013, from http:// www.metrolyrics.com/welcome-to-jamrock-lyrics-damian-marley.html

Martin, T. (ed.), 1986, Marcus Garvey: Message to the people, The course of African philosophy, The Majority Press, Massachusetts.

Matthews, G.C. (ed.), 2013, Building peace on earth: Report of the International Ecumenical Peace Convocation, WCC Publications, Geneva.

Noris, K., 1962, The search for an identity, Oxford University Press, London.

Prahlad Anand, S., 2001, Reggae wisdom, University Press of Mississippi, Jackson.

Ross, K.R., Nilsson, E.C. \& Hewitt, R., 2014, 'Busan and beyond: Taking forward the new WCC mission affirmation together towards life', International Review of Mission 103(1), 3-17. http://dx.doi.org/10.1111/irom.12032

Sheerattan-Bisnauth, P. (ed.), 2009, Power to resist and courage to hope: Caribbean churches living out the Accra Confession, World Alliance of Reformed Churches, Geneva.

Smith, A., 1991, Emerging from innocence: Religion, theology and development, Ureke Press, Mandeville.

Swidler, L., 2013, Can there be a spirituality of democracy?, viewed 28 October 2013, from http://www.arcc-catholic-rights.net/lenten_1.htm

The Church and Economic Globalisation, 2007, The Commission on Internationa Affairs, Church of Norway Council on Ecumenical and International Relations, Oslo.

The Phrase Finder, n.d., The meaning and origin of the expression: Power corrupts; absolute power corrupts absolutely, viewed 11 November 2013, from http:// www.phrases.org.uk/meanings/absolute-power-corrupts-absolutely.html

Van der Water, D., Apawo Phiri, I., Kang, N., Hewitt, R. \& Nadar, S. (eds.), 2011 Postcolonial mission, power and partnership in world Christianity, Sopher Press, Upland, California. 